\title{
Penguatan Umkm Melalui Peningkatan Kualitas Dan Legalitas Pada Pengusaha Makanan Kota Tegal
}

\author{
MAULIDA DWI KARTIKASARI \\ Universitas Pancasakti Tegal \\ Jln. Halmahera km 1 Tegal Telp. (0283) 354093 \\ E-mail : maulidadwikartikasari@upstegal.ac.id
}

\begin{abstract}
One of the community of food entrepreneurs in Tegal City is the "Raja Squad". The community has been around since 2016 with a variety of culinary entrepreneurs. In this community every month there is always a meeting to cut ties and share information. As for the methods used in the service of devotion to this community are individual, group presentations, demonstrations and practices. the result of devotion to this community is the improvement of quality in the form of improved packaging and in accordance with health rules. Increased legality due to product registration in the health department and the emergence of no PIRT.
\end{abstract}

Keywords: packaging, legality

Kota Tegal berada di Wilayah pantai utara, dari peta orientasi Provinsi Jawa Tengah berada di Wilayah Barat, dengan bentang terjauh utara ke Selatan 6,7 Km dan Barat ke Timur 9,7 Km. Dilihat dari Letak Geografis, Posisi Kota Tegal sangat strategis sebagai pusat industri kuliner. Salah satu komunitas pengusaha makanan di Kota Tegal adalah "Raja Squad". Komunitas ini berdiri sejak tahun 2016 yang terdiri dari berbagai macam pengusaha kuliner. Pada komunitas ini setiap bulan selalu diadakan pertemuan guna mempererat tali silaturahim dan berbagi informasi. Bolen bohay dan Ayam Ungkep "Almira' merupakan 2 dari 20 anggota komunitas ini.

Upaya pengingkatan kualitas pada pengusaha makanan ini adalah dengan memperbaiki kemasan agar lebih menarik serta mendaftarkan perijinan makanan di Dinas Kesehatan. Perbaikan kemasan sangat penting agar konsumen lebih tertarik untuk membeli produk. Kemasan yang semula berfungsi hanya sebagai wadah atau bungkus yang berfungsi melindungi produk agar mudah dibawa, kini berubah menjadi nilai jual yang menunjukkan keunggulan sebuah merek. Setiap perancangan kemasan dituntut suatu ide yang menunjukkan performance suatu produk sehingga tampilan desain mampu menarik hati konsumen. Upaya peningkatan kualitas selanjutanya adalah perijinan kelayakan makanan di Dinas Kesehatan melalui terbitnya Nomor PIRT (Pengusaha Industri Rumah Tangga) yang dicantumkan dalam sebuah kemasan. Melalui Nomor PIRT, kualitas suatu produk akan lebih diakui dan dipercaya oleh masyarakat.

Bolen Bohay dan Ayam Ungkep "Almira" merupakan dua pengusaha makanan yang sedang banyak meraup keuntungan di bidangnya masing-masing. Kedua mitra sudah memiliki pelanggan dan reseller. Omset di setiap bulannya juga mengalami peningkatan. Bolen Bohay menyediakan aneka macam kue kering dan pastry. Demikian pula yang dialami oleh ibu Ika, pemilik ayam ungkep Almira. Usaha rumahan ini menjual berbagai masakan ungkep siap goreng. Usaha ini berlokasi di Desa Mejasem namun pangsa pasarnya sudah sampai ke luar kota. Usaha ini mulai berjalan bulan Januari 2018. Berawal dari mengisi waktu luang, akhirnya ibu Ika bisa mengembangkan usahanya dengan sukses. Menu yang disediakan adalah 
ayam dan bebek ungkep siap goreng. Pemasaran dilakukan menggunakan sistem online dan delivery order. Selain itu juga Ibu Ika menitipkan dagangannya di beberapa pusat perbelanjaan di Kota Tegal. Pemilik juga ikut aktif berjualan di car free day alun-alun Kota Tegal.

\section{METODE}

Kegiatan pengabdian kepada masyarakat ini ditujukan untuk memberikan pengetahuan dan ketrampilan pembuatan kemasan produk olahaman makanan pada pengusaha kue Bolen Bohay dan Ayam Ungkep "Almira. Adapun metode yang digunakan dalam kegiatan ini adalah presentasi, demonstrasi, dan praktik secara individu maupun kelompok.

a. Metode presentasi

Metode ini digunakan untuk menyampaikan beberapa hal yang berkaitan dengan manfaat, fungsi, bahan alat, bagaimana cara membuat kemasan dan pentingnya nomor PIRT sebagai sarana menciptakan kepercayaan pada pelanggan.

b. Metode Demonstrasi

Metode ini digunakan untuk mempertunjukkan cara pembuatan kemasan produk makanan. Diharapkan dengan adanya metode ini para peserta dapat mempraktikkan langsung dengan prosedur pembuatan. Penjelasan prosedur mengenai tahapan pengurusan nomor PIRT

c. Metode Praktik

Metode ini dilakukan untuk melatih para pengusaha makanan dalam membuat kemasan. Metode ini dilakukan agar para pengusaha makanan tersebut mempunyai pengalaman langsung dengan pembuatan kemasan

\section{HASIL}

Setelah proses pengurusan legalitas selama 3 bulan di Dinas Kesehatan, akhirnya "Bolen Bohay sudah memiliki Nomor PIRT. Berikut sertifikat yang diperoleh Ibu Lisnawati/Bapak Adi Tri atas nomor PIRT. "Bolen Bohay" juga sudah semakin meningkatkan proses pemasaran melalui Google. Sehingga pelanggan sudah bisa melihat produk-produk "Bolen Bohay" di Google sehingga sarana pemasaran sudah meluas. Berikut ini adalah sertifikat Nomor PIRT milik "Bolen Bohay".

Perubahan kemasan yang dilakukan Ibu Ika memang belum terlalu terlihat mencolok. Karena dari awal memang ibu Ika sudah memahami pentingnya identitas suuatu produk. Semenjak awal penjualannya, Ibu Ika sudah mencantumkan kemasan berupa merek produk di kemasannya. Namun ada perubahan dari sisi perlekatan yang semula menggunakan stapler saat ini menggunakan sealer. Perubahan tersebut dilakukan Ibu Ika setelah mengikuti pelatihan, bahwa produk makanan tidak diperbolehkan melekatkan dengan menggunakan stapler karena berbahaya apabila tertelan oleh konsumennya.

\section{PEMBAHASAN}

Pelatihan ini memberikan materi yang berkaitan dengan upaya untuk meningkatkan kemampuan pengusaha makanan di Kota Tegal dalam pembuatan kemasan makanan yang bernilai jual tinggi. Selain itu para pengusaha makanan juga diberikan materi dan langkah-langkah dalam proses perijinan layak edar serta memberikan kesadaran pentingnya mencantumkan legalitas pada kemasan sebagai upaya peningkatan kepercayaan pada masyarakat. Para peserta sangat antusias dalam menerima materi yang diberikan oleh pengabdi. Jumlah peserta yang hadir adalah 9 yang keseluruhannya merupakan pengusaha kuliner di Kota Tegal.

Kegiatan pengabdian masyarakat ini dilaksanakan sebanyak 4 kali pertemuan. Pelatihan ini dimulai sejak bulan Desember 2018, Januari, Februari, dan Maret 2019. Pelatihan program ini melibatkan 1 narasumber yaitu Ibu Ayu paramita. Ibu Ayu Paramita merupakan pengusaha kuliner di bidang kopi. Ibu ayu ini sudah memasarkan produknya sampai ke selurun Indonesia. Beliau juga menerima jasa pembuatan desain kemasan makanan. 
Kegiatan pengabdian ini melibatkan narasumber dari luar dikarenakan para peserta membutuhkan materi sekaligus pengalaman dari praktisi pengusaha kuliner langsung.

Langkah awal perubahan kemasan tersebut dapat merujuk pada kemasan yang digunakan pengusaha makanan "Ayam Ungkep Almira" dan "Bolen Bohay". Sebagai rintisan kemasan yang baik adalah dengan menambahkan stiker pada box makanan. Dengan adanya stiker setidaknya ada identitas yang tercantum pada kemasan. Selain itu penting "branding" yang muncul pada kemasan. Berdasarkan hasil pengabdian masyarakat sebelumnya mengenai pentingnya branding pada produk makanan, "Ayam Ungkep Almira" dan "Bolen Bohay" sudah mampu menerapkan indentitas produk pada kemasan.

Hasil evaluasi dilaksanakan pada bulan Maret 2019. Beberapa pengusaha makanan, seperti Bolen Bohay, Ayam Ungkep Almira, dan Pizza Kampoeng sudah memiliki minat untuk memperbaiki kemasan. Meskipun masih ada beberapa yang belum memiliki keinginan untuk memperbaiki kemasan, namun pelatihan ini membuka mata dan pikiran para pengusaha makanan untuk memperbaiki kemasan serta pengurusan legalitas makanan. Tidak hanya perbaikan dari sisi kemasan, "Bolen Bohay" juga memperbaiki kualitas dari sisi legalitas.

Hasil evaluasi menunjukkan pada saat awal pertemuan menunjukkan bahwa dari 9 peserta yang menghadiri pelatihan, diperoleh data ada 6 peserta belum memiliki identitas kemasan. Sebagian besar masih menggunakan dus makanan yang dijual di pasaran. Tentu saja hasil tersebut kurang menarik bagi calon pembeli. Selain itu, tidak adanya satupun produk yang memiliki ijin legalitas makanan. Setelah dilakukan diskusi dengan para peserta, ternyata proses pembuatan kemasan yang menarik memang memerlukan biaya yang cukup tinggi. Hal tersebut disebabkan proses pemesanan harus dalam jumlah yang sangat besar. Untuk ukuran pengusaha lokal mereka lebih memilihi sebagai tambahan modal disbanding membuat kemasan. Pada pertemuan kedua dihadirkan seorang narasumber dalam hal ini adalah Ibu Ayu Paramita yang merupakan praktisi pengusaha kuliner. Para peserta sangat antusias dengan materi kemasan tersebut. Kegiatan tanya jawab dilakukan bersamaan dengan penyajian materi. Para peserta dapat langsung berdiskusi dengan para pemateri secara langsung untuk memahamkan materi dan sharing pengalaman terkait dengan masalah yang tengah dibahas dalam materi bersangkutan. Narasumber memberikan penekanan, bahwa kemasan yang menarik mampu meningkatkan nilai jual bagi produk. Kemudian pada pertemuan berikutnya narasumber memberikan materi mengenai pentingnya mencantumkan legalitas pada kemasan. Narasumber memberikan langkah-langkah dalam proses pengurusan No PIRT serta sertifikat halal. Selain kemasan, pencantuman kehalalan produk juga menambah kepercayaan bagi masyarakat.

Pada pertemuan terakhir yaitu pertemuan keempat pelatihan merupakan evaluasi dari proses pelatihan selama 3 kali pertemuan ini.

Setelah proses pengurusan legalitas selama 3 bulan di Dinas Kesehatan, akhirnya "Bolen Bohay sudah memiliki Nomor PIRT. Berikut sertifikat yang diperoleh Ibu Lisnawati/Bapak Adi Tri atas nomor PIRT. "Bolen Bohay" juga sudah semakin meningkatkan proses pemasaran melalui Google. Sehingga pelanggan sudah bisa melihat produk-produk "Bolen Bohay" di Google sehingga sarana pemasaran sudah meluas. Berikut ini adalah sertifikat Nomor PIRT milik "Bolen Bohay".

Perubahan kemasan yang dilakukan Ibu Ika memang belum terlalu terlihat mencolok. Karena dari awal memang ibu Ika sudah memahami pentingnya identitas suuatu produk. Semenjak awal penjualannya, Ibu Ika sudah mencantumkan kemasan berupa merek produk di kemasannya. Namun ada perubahan dari sisi perlekatan yang semula menggunakan stapler saat ini menggunakan sealer. 
Perubahan tersebut dilakukan Ibu Ika setelah mengikuti pelatihan, bahwa produk makanan tidak diperbolehkan melekatkan dengan menggunakan stapler karena berbahaya apabila tertelan oleh konsumennya. Pada pengusaha makanan yang lain masih berusaha untuk menyesuaikan kondisi. Karena memang sebagian besar dari mereka omzetnya bisa dikatakan tergolong kecil sehingga untuk melakukan perbaikan kemasan dirasakan masih berat. Namun, secara bertahap akan dilakukan kembali pelatihan mengenai pemasaran online. Tujuannya adalah untuk meningkatkan omzet penjualan

\section{SIMPULAN}

Dari hasil kegiatan pengabdian kepada masyarakat ini diperoleh hasil bahwa kemasan sangat mempengaruhi penjualan. Adanya identitas pada kemasan menunjukkan jatidiri sebuah produk. Omzet penjualan pada pengusaha yang memperbaiki kualitas kemasan menjadi semakin meningkat. Selain itu pentingnya legalitas melalui Nomor PIRT yang dicantumkan pada kemasan, memberikan tambahan kepercayaan pada konsumen. menggunakan sealer sehingga kemasan ini lebih aman bagi konsumen.

\section{DAFTAR RUJUKAN}

1999, Undang-undang No. 8 Tahun 1999 Perlindungan Konsumen. Jakarta

LPPM Universitas Pancasakti Tegal. 2016. Pedoman Pelaksanaan Penelitian dan Pengabdian Kepada Masyarakat.Tegal 